\title{
Isoptericola nanjingensis sp. nov., a mineral-weathering bacterium
}

Correspondence

Xia-Fang Sheng

xfsheng604@sohu.com

\author{
Zhi Huang, Xia-Fang Sheng, Fei Zhao, Lin-Yan He, Jing Huang \\ and Qi Wang
}

Key Laboratory of Microbiological Engineering of Agricultural Environment, Ministry of Agriculture, College of Life Science, Nanjing Agricultural University, Nanjing 210095, PR China

\begin{abstract}
A Gram-positive-staining, non-motile, rod- or coccoid-shaped actinobacterium, designated strain $\mathrm{H} 17^{\top}$, was isolated from a soil sample from Nanjing, Jiangsu Province, PR China. The organism grew optimally at $30{ }^{\circ} \mathrm{C}, \mathrm{pH} 7.0$ and with $3 \% \mathrm{NaCl}(\mathrm{w} / \mathrm{v})$. Strain $\mathrm{H} 17^{\mathrm{T}}$ contained L-Lys-D-Asp as the cell-wall peptidoglycan type and galactose, xylose and mannose as the whole-cell sugars. The major fatty acids were anteiso- $C_{15: 0}$ and iso- $C_{15: 0}$. The total polar lipids were diphosphatidylglycerol, phosphatidylglycerol, phospholipids, phosphatidylinositol, phosphoglycolipid, one unidentified glycolipid and one unidentified lipid. The menaquinone was MK9 $\left(\mathrm{H}_{4}\right)$. Mycolic acids were not detected. The DNA G+C content was $72.4 \mathrm{~mol} \%$. Phylogenetic analysis of this strain based on 16S rRNA gene sequences revealed 97.8-99.6\% similarity to recognized species of the genus /soptericola. The low level of DNA-DNA relatedness to other species of the genus /soptericola and the many phenotypic properties that distinguished strain $\mathrm{H} 17^{\top}$ from recognized species of this genus demonstrated that isolate $\mathrm{H} 17^{\top}$ should be classified as representing a novel species of the genus /soptericola. The name /soptericola nanjingensis sp. nov. is proposed for this novel species. The type strain is $\mathrm{H} 17^{\top}$ (=DSM

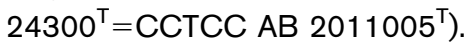

The genus Isoptericola was proposed by Stackebrandt et al. (2004) to accommodate an atypical species of the genus Cellulosimicrobium, Cellulosimicrobium variabile (Bakalidou et al., 2002). Currently, the genus Isoptericola comprises six species with validly published names: Isoptericola variabilis (Stackebrandt et al., 2004), I. hypogeus (Groth et al., 2005), I. halotolerans (Zhang et al., 2005), I. dokdonensis (Yoon et al., 2006), I. jiangsuensis ( $\mathrm{Wu}$ et al., 2010) and I. chiayiensis (Tseng et al., 2011). In this study, a bacterial strain, $\mathrm{H}^{\mathrm{T}}{ }^{\mathrm{T}}$, was characterized that was phylogenetically closely related to the genus Isoptericola.

Strain $\mathrm{H} 17^{\mathrm{T}}$ was isolated from a soil sample using the dilution plating method on a sucrose-mineral salts medium. This medium contained $\left(\mathrm{l}^{-1}\right): 10.0 \mathrm{~g}$ sucrose, $0.5 \mathrm{~g}$ yeast extract, $1 \mathrm{~g}\left(\mathrm{NH}_{4}\right)_{2} \mathrm{SO}_{4}, 2 \mathrm{~g} \mathrm{~K}_{2} \mathrm{HPO}_{4}, 0.5 \mathrm{~g} \mathrm{MgSO}_{4}, 0.1 \mathrm{~g} \mathrm{NaCl}, 0.5 \mathrm{~g}$ $\mathrm{CaCO}_{3}$ and $15 \mathrm{~g}$ agar. Strain $\mathrm{H}_{1}{ }^{\mathrm{T}}$ was able to weather potassium-bearing minerals. Morphology and motility were examined by light microscopy (CX21; Olympus) and transmission electron microscopy (H-7650; Hitachi) using cells from the exponential phase. The determination of the optimal growth temperature was performed using trypticase soy agar (TSA) at $4,10,20,37$ and $42{ }^{\circ} \mathrm{C}$. The $\mathrm{pH}$ range for

The GenBank/EMBL/DDBJ accession number for the $16 \mathrm{~S}$ rRNA gene sequence of strain $\mathrm{H}_{17} 7^{\top}$ is $\mathrm{HO} 222356$.

Supplementary figures are available with the online version of this paper. growth was determined in nutrient broth adjusted to various $\mathrm{pH}$ values ( $\mathrm{pH} 4.5-10.5$ at intervals of $0.5 \mathrm{pH}$ units) with $\mathrm{HCl}$ or $\mathrm{Na}_{2} \mathrm{CO}_{3}$. To investigate tolerance of $\mathrm{NaCl}$, trypticase soy broth was used and the $\mathrm{NaCl}$ concentration was altered $(0,0.5,1.0-10.0 \%, \mathrm{w} / \mathrm{v}$, at intervals of $1.0 \%)$. Standard physiological tests were performed according to the methods described by Gordon et al. (1974) and Lányí (1987). Susceptibility to antibiotics was tested on TSA plates using discs containing the following concentrations of antibiotics: carbenicillin, $100 \mu \mathrm{g}$; chloramphenicol, $30 \mu \mathrm{g}$; gentamicin, $10 \mu \mathrm{g}$; kanamycin, $30 \mu \mathrm{g}$; lincomycin, $2 \mu \mathrm{g}$; midecamycin, $30 \mu \mathrm{g}$; neomycin, $30 \mu \mathrm{g}$; novobiocin, $30 \mu \mathrm{g}$; polymyxin $\mathrm{B}$, $30 \mu \mathrm{g}$; rifampicin, $5 \mu \mathrm{g}$; spectinomycin, $100 \mu \mathrm{g}$; streptomycin, $10 \mu \mathrm{g}$; tetracycline, $30 \mu \mathrm{g}$ and vancomycin, $30 \mathrm{U}$. Metabolic properties and enzyme activities were tested using API $50 \mathrm{CHB} / \mathrm{E}$ and API ZYM systems (bioMérieux) according to the manufacturer's instructions.

Growth of strain $\mathrm{H} 17^{\mathrm{T}}$ was aerobic and cells were Gramstain positive. Both coccoid- and rod-shaped cells were observed, but neither flagella nor spores were found (see Fig. S1 in IJSEM Online). Colonies on TSA were pale yellow, with a smooth surface and diameter of 1.0-2.0 mm after incubation for $48 \mathrm{~h}$ at $30{ }^{\circ} \mathrm{C}$. Strain $\mathrm{H} 17^{\mathrm{T}}$ could grow at $10-37{ }^{\circ} \mathrm{C}$ (optimum $30{ }^{\circ} \mathrm{C}$ ), at $\mathrm{pH} 5.5-10$ (optimum $\mathrm{pH} 7.0$ ) and with $0.5-10 \% \mathrm{NaCl}$ (w/v; optimum $3 \%$ ). Detailed physiological and biochemical 
Table 1. Phenotypic characteristics of strain $\mathrm{H} 17^{\top}$ and other species of the genus /soptericola

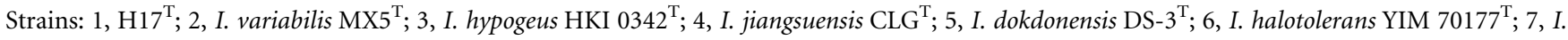
chiayiensis $06182 \mathrm{M}-1^{\mathrm{T}}$. All taxa are positive for Gram-staining, catalase, hydrolysis of aesculin and starch, utilization of glycerol, L-arabinose, Dxylose, D-galactose, D-glucose, D-fructose, D-mannose, arbutin, salicin, cellobiose, maltose, sucrose, starch, glycogen and for the activity of esterase lipase (C8), leucine arylamidase, valine arylamidase, cystine arylamidase, naphthol-AS-BI-phosphohydrolase, $\beta$-galactosidase, $\alpha$ - and $\beta$-glucosidase. All strains are susceptible to carbenicillin $(100 \mu \mathrm{g})$, chloramphenicol $(30 \mu \mathrm{g})$, gentamicin $(10 \mu \mathrm{g})$, neomycin $(30 \mu \mathrm{g})$, novobiocin $(30 \mu \mathrm{g})$, polymyxin B $(30 \mu \mathrm{g})$, roxithromycin $(15 \mu \mathrm{g})$, tetracycline $(30 \mu \mathrm{g})$ and vancomycin $(30 \mathrm{U})$. All taxa are negative for motility, utilization of erythritol, L-xylose, D-adonitol, L-sorbose, dulcitol, inositol, D-sorbitol, xylitol, D-tagatose, D-fucose, L-arabitol, L-fucose, potassium gluconate, potassium 2- and 5-ketogluconate and are not susceptible to kanamycin $(30 \mu \mathrm{g})$. +, Positive; w, weakly positive; -, negative.

\begin{tabular}{|c|c|c|c|c|c|c|c|}
\hline Characteristic & 1 & 2 & 3 & 4 & 5 & 6 & 7 \\
\hline Oxidase & + & + & - & - & + & + & - \\
\hline \multicolumn{8}{|l|}{ Growth at/with: } \\
\hline $42{ }^{\circ} \mathrm{C}$ & - & + & - & - & - & - & - \\
\hline $10 \% \mathrm{NaCl}(\mathrm{w} / \mathrm{v})$ & + & + & - & + & - & + & + \\
\hline \multicolumn{8}{|l|}{ Hydrolysis of: } \\
\hline Casein & - & + & + & - & - & - & - \\
\hline Gelatin & - & + & + & - & + & - & - \\
\hline Hypoxanthine & + & + & + & - & - & - & - \\
\hline Tyrosine & - & + & - & - & - & - & - \\
\hline Urea & - & + & - & - & - & - & - \\
\hline Xanthine & + & + & + & - & - & - & - \\
\hline Nitrate reduction & - & + & + & + & + & - & - \\
\hline Methyl red & + & + & - & - & - & - & - \\
\hline Indole & - & + & - & - & + & + & + \\
\hline \multicolumn{8}{|l|}{ Utilization of: } \\
\hline D-Arabinose & - & + & - & - & - & $\mathrm{w}$ & w \\
\hline D-Ribose & + & + & - & + & - & + & w \\
\hline L-Rhamnose & + & + & - & $\mathrm{w}$ & - & - & + \\
\hline D-Mannitol & + & + & - & - & - & + & - \\
\hline Lactose & + & + & - & + & - & - & - \\
\hline Melibiose & + & - & - & + & - & - & - \\
\hline Trehalose & + & - & - & + & + & - & w \\
\hline Melezitose & + & + & - & + & - & - & - \\
\hline Raffinose & + & + & - & + & - & - & - \\
\hline Turanose & + & + & - & + & + & + & - \\
\hline D-Lyxose & + & - & - & - & - & - & - \\
\hline D-Arabitol & + & + & $\mathrm{w}$ & - & - & - & w \\
\hline $\begin{array}{l}\text { Methyl } \\
\beta \text {-D-xylopyranoside }\end{array}$ & + & - & - & - & - & - & - \\
\hline $\begin{array}{l}\text { Methyl } \\
\alpha \text {-D-mannopyranoside }\end{array}$ & + & - & - & - & - & - & - \\
\hline $\begin{array}{l}\text { Methyl } \\
\alpha \text {-D-glucopyranoside }\end{array}$ & + & + & - & + & - & - & - \\
\hline$N$-Acetylglucosamine & + & + & - & + & - & - & - \\
\hline Amygdalin & + & + & + & + & - & + & - \\
\hline Inulin & + & - & - & + & - & + & - \\
\hline Gentiobiose & + & + & - & + & - & + & + \\
\hline \multicolumn{8}{|l|}{ API ZYM tests: } \\
\hline Alkaline phosphatase & + & + & - & + & + & - & + \\
\hline Esterase $(\mathrm{C} 4)$ & + & + & - & + & - & + & + \\
\hline Lipase (C14) & + & + & - & + & $\mathrm{w}$ & $\mathrm{w}$ & + \\
\hline Trypsin & - & + & - & + & + & + & + \\
\hline$\alpha$-Chymotrypsin & - & + & - & + & + & - & + \\
\hline Acid phosphatase & - & - & - & + & + & - & - \\
\hline$\alpha$-Galactosidase & + & + & - & + & - & - & - \\
\hline$\beta$-Glucuronidase & + & + & - & - & - & - & - \\
\hline
\end{tabular}


Table 1. cont.

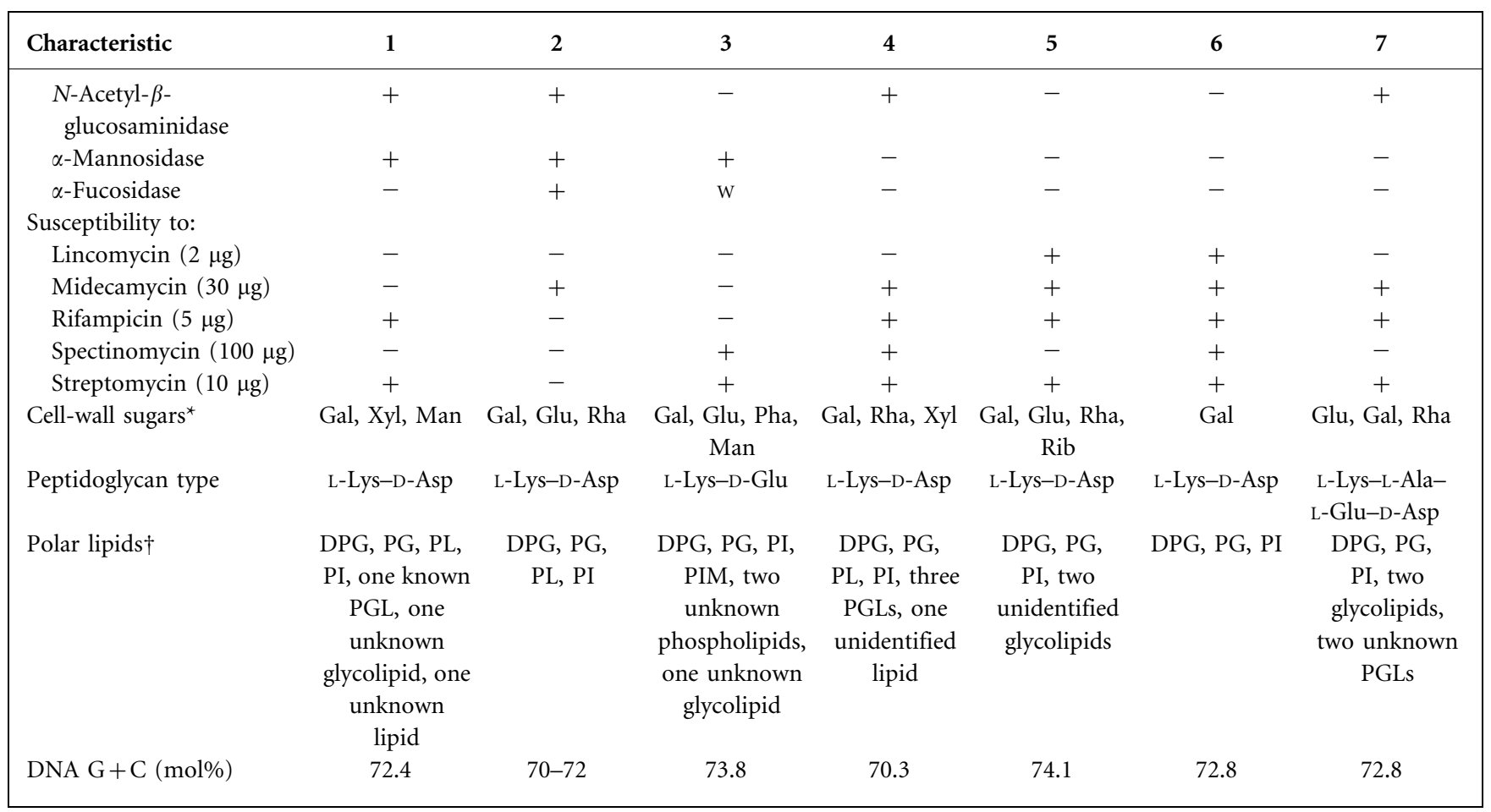

${ }^{\star} \mathrm{Gal}$, Galactose; Glu, glucose; Man, mannose; Rha, rhamnose; Rib, ribose; Xyl, xylose.

$†$ DPG, Diphosphatidylglycerol; PG, phosphatidylglycerol; PGL, phosphoglycolipid; PI, phosphatidylinositol; PIM, phosphatidylinositol mannoside; PL, phospholipids.

characteristics of the strain are given in Table 1 and the species description.

The chemotaxonomic characteristics of strain $\mathrm{H}_{17}{ }^{\mathrm{T}}$ were determined using cells cultured on TSA. The elucidation of the peptidoglycan structure was carried out as described by Schleifer (1985) and Schleifer \& Kandler (1972) with the modification that TLC on cellulose was used instead of paper chromatography. Quantitative analysis of amino acids was carried out by GC by using a EZ:faast kit (Phenomenex) according to the manufacturer's instructions. Calibration was achieved by using a standard composed of peptidoglycan relevant amino acids. For analysis of the cell-wall sugars, the cell-wall preparation was hydrolysed with $0.5 \mathrm{M} \mathrm{H}_{2} \mathrm{SO}_{4}(2 \mathrm{~h}$ at $\left.100{ }^{\circ} \mathrm{C}\right) . \mathrm{H}_{2} \mathrm{SO}_{4}$ was removed by $20 \% \mathrm{~N}, \mathrm{~N}$-dioctylmethylamine in chloroform according to Whiton et al. (1985). The sugars in the hydrolysate were analysed by TLC on cellulose plates according to Staneck \& Roberts (1974). For polar lipid analysis, cell mass of strain $\mathrm{H}_{1} 7^{\mathrm{T}}$ was harvested from tryptic soy broth after incubation for $20 \mathrm{~h}$ at $30{ }^{\circ} \mathrm{C}$. Polar lipids were extracted from $100 \mathrm{mg}$ freeze-dried cell material using the two-stage method described by Tindall (1990a, b) and were identified using two-dimensional silica gel TLC followed by spraying with appropriate detection reagents (Art. No. 818 135; Macherey-Nagel). The polar lipid analysis was carried out by the DSMZ. For fatty acid methyl ester analysis, cell mass of strain $\mathrm{H}_{17} 7^{\mathrm{T}}$ was harvested from TSA plates after incubation for 2 days (exponential phase) at $30{ }^{\circ} \mathrm{C}$. The fatty acid methyl esters were extracted and prepared according to the protocol of Miller (1982) with minor modifications from Kuykendall et al. (1988). The fatty acid methyl ester mixtures were separated using the Sherlock Microbial Identification System (MIS) (MIDI, Microbial ID), which consisted of a GC $(6890 \mathrm{~N}$; Agilent) fitted with a $5 \%$ phenyl-methyl silicone capillary column $(0.2 \mathrm{~mm} \times 25 \mathrm{~m})$, a flame-ionization detector, an automatic sampler (7683A; Agilent) and a computer (Hewlett Packard) running the MIDI database. Menaquinones were extracted and purified by the methods of Collins et al. (1977) and Tamaoka et al. (1983) and then analysed by HPLC (1100; Agilent) with a Zorbax EclipseXDB-C18.5 column $(250 \times 4.6 \mathrm{~mm})$. Mycolic acids were examined by TLC as described by Minnikin et al. (1980).

The total hydrolysate of the cell-wall peptidoglycan of strain $\mathrm{H} 17^{\mathrm{T}}$ contained alanine and glutamic acid with smaller amounts of lysine and aspartic acid. In addition, the peptide L-Lys-D-Asp was detected, which was stable under the hydrolysis conditions $\left(100{ }^{\circ} \mathrm{C}, 4 \mathrm{M} \mathrm{HCl}, 16 \mathrm{~h}\right)$. Quantitative analysis of the peptidoglycan amino acids after hydrolysis under stronger conditions $\left(120{ }^{\circ} \mathrm{C}, 6 \mathrm{M} \mathrm{HCl}, 16 \mathrm{~h}\right)$ by using the EZ:faast kit resulted in the following quantitative ratio: 0.6 Ala:0.3 Asp : 1.0 Glu:0.5 Lys. The reduced amounts of lysine and aspartic acid were due to the occurrence of the stable peptide L-Lys-D-Asp. Partial hydrolysis $\left(100{ }^{\circ} \mathrm{C}, 4 \mathrm{M}\right.$ $\mathrm{HCl}, 45 \mathrm{~min}$ ) resulted in the additional peptides L-Ala-DGlu, D-Asp-L-Lys-D-Ala and L-Lys-D-Ala. From these data, 
Table 2. Fatty acid profiles $(>1 \%)$ of strain $\mathrm{H} 17^{\top}$ and type strains of the genus /soptericola

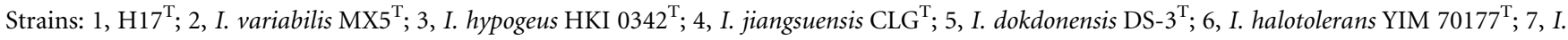
chiayiensis $06182 \mathrm{M}-1^{\mathrm{T}}$.

\begin{tabular}{|c|c|c|c|c|c|c|c|}
\hline Fatty acid (\%) & 1 & 2 & 3 & 4 & 5 & 6 & 7 \\
\hline $\mathrm{C}_{14: 0}$ & 5.97 & 6.6 & - & 1.17 & 3.3 & 2.33 & 1.75 \\
\hline $\mathrm{C}_{15: 0}$ & - & - & - & 2.64 & 2.6 & - & - \\
\hline $\mathrm{C}_{16: 0}$ & 8.32 & 7.2 & - & 3.13 & 9.0 & 20.05 & 9.72 \\
\hline $\mathrm{C}_{17: 0}$ & - & - & - & 1.24 & - & - & 1.48 \\
\hline iso- $\mathrm{C}_{13: 0}$ & - & - & - & 3.98 & 1.1 & - & - \\
\hline iso- $\mathrm{C}_{14: 0}$ & 2.13 & 1.5 & 8.4 & 3.40 & 4.2 & - & 3.01 \\
\hline iso- $\mathrm{C}_{15: 0}$ & 22.35 & 17.0 & 18.1 & 14.29 & 11.5 & 7.02 & 12.02 \\
\hline iso- $\mathrm{C}_{16: 0}$ & 7.57 & 6.0 & 22.6 & 1.39 & 3.0 & 1.44 & 5.02 \\
\hline iso- $\mathrm{C}_{17: 0}$ & - & - & - & 1.09 & - & - & 1.37 \\
\hline anteiso- $\mathrm{C}_{15: 0}$ & 48.63 & 53.6 & 44.0 & 60.06 & 58.6 & 54.46 & 55.04 \\
\hline anteiso- $\mathrm{C}_{17: 0}$ & 3.45 & 7.0 & 3.1 & 5.44 & 41.0 & 10.69 & 8.77 \\
\hline
\end{tabular}

it was concluded that strain $\mathrm{H} 17^{\mathrm{T}}$ showed peptidoglycan type A $4 \alpha$, based on L-Lys-D-Asp.

Whole-cell sugars were detected with galactose present in large amounts, with smaller amounts of xylose and traces of mannose. This profile was different from that found for other species of the genus Isoptericola. Strain $\mathrm{H}_{1} 7^{\mathrm{T}}$ contained diphosphatidylglycerol, phosphatidylglycerol, phospholipids, phosphatidylinositol, phosphoglycolipid, one unidentified glycolipid and one unidentified lipid (see Fig. S2). The fatty acid profile ( $>0.5 \%$ of total fatty acids) of strain $\mathrm{H} 17^{\mathrm{T}}$ comprised branched fatty acids anteiso- $\mathrm{C}_{15: 0}$ $(48.63 \%)$, iso- $\mathrm{C}_{15: 0}(22.35 \%)$, iso- $\mathrm{C}_{16: 0}(7.57 \%)$, anteiso$\mathrm{C}_{17: 0}(3.45 \%)$, iso- $\mathrm{C}_{14: 0}(2.13 \%)$ and iso- $\mathrm{C}_{17: 0}(0.52 \%)$ and straight-chain fatty acids $\mathrm{C}_{16: 0}(8.32 \%), \mathrm{C}_{14: 0}(5.97 \%)$ and $\mathrm{C}_{15: 0}(0.91 \%)$ (Table 2). The menaquinone was MK9 $\left(\mathrm{H}_{4}\right)$. Mycolic acids were not detected.

For analysis of the 16S rRNA gene sequence, bacterial DNA was extracted using a Qiagen Genomic DNA kit. The $16 S$ rRNA gene was PCR-amplified using universal primers according to the methods of Timke et al. (2005) and directly sequenced on a sequencer (ABI 3730; Invitrogen). Phylogenetic analysis was performed using the MEGA (version 4.0) software after multiple alignments of data using
CLUSTAL_X. Distances were calculated according to the distance options with Kimura's two-parameter model and clustering with the neighbour-joining, minimum-evolution and the unweighted pair group method with arithmetic means (UPGMA) algorithms. Bootstrap values were determined based on 1000 replications. The neighbour-joining tree is shown in Fig. 1. The minimum-evolution and UPGMA trees are available as Figs S3 and S4. The DNA G + C content of strain $\mathrm{H}_{1}{ }^{\mathrm{T}}$ was determined by the thermal denaturation method (Marmur \& Doty, 1962) using Escherichia coli K-12 as a reference. DNA-DNA hybridization was carried out as described by De Ley et al. (1970) using a UV/VIS spectrophotometer (UV1201; Rayleigh).

A total of $1404 \mathrm{bp}$ of the 16S rRNA gene sequence was sequenced. The sequence was subjected to similarity searches by using the sequence matching tool of the NCBI BLAST program (http://www.ncbi.nlm.nih.gov), Ribosomal Database Project II (http://rdp.cme.msu.edu/) and EzTaxon (http://www.eztaxon.org/; Chun et al. 2007). Comparative $16 \mathrm{~S}$ rRNA gene sequence analysis showed that strain $\mathrm{H} 17^{\mathrm{T}}$ was most closely related to members of the genus Isoptericola. The 16S rRNA gene sequence of strain $\mathrm{H}_{1} 7^{\mathrm{T}}$ showed similarities of $99.6 \%, 98.4 \%, 98.2 \%, 98.1 \%, 98.0 \%$ and $97.8 \%$ with those of I. variabilis $\mathrm{MX}^{\mathrm{T}}$, I. hypogeus HKI

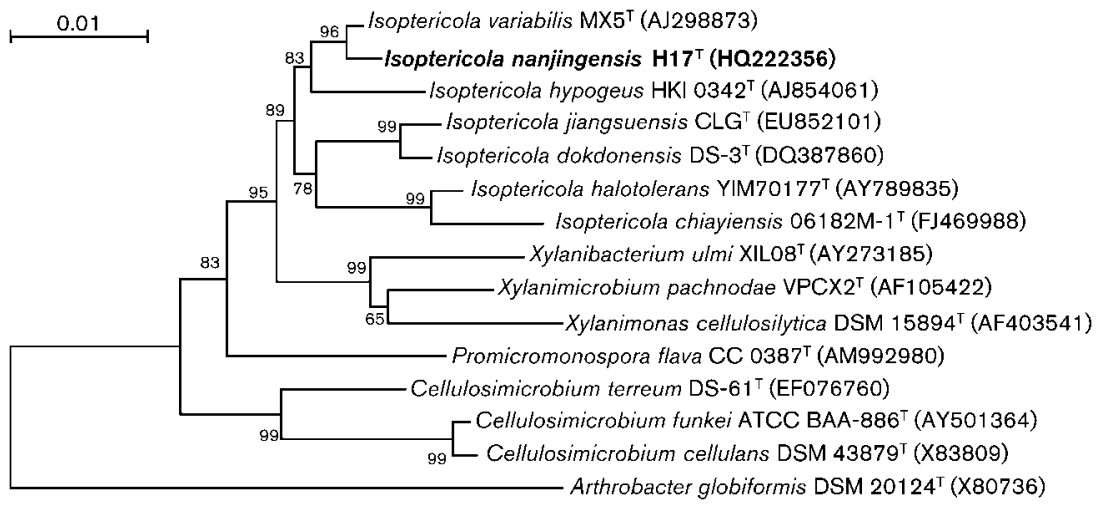

Fig. 1. Neighbour-joining phylogenetic tree based on 16S rRNA gene sequences showing the positions of strain $\mathrm{H} 17^{\top}$, species of the genus Isoptericola and some other related taxa. Numbers at nodes are bootstrap values based on 1000 resamplings; only values $>50 \%$ are given. Arthrobacter globiformis DSM $20124^{\top}$ was used as an outgroup. Bar, 0.01 substitutions per nucleotide position. 
$0342^{\mathrm{T}}$, I. jiangsuensis $\mathrm{CLG}^{\mathrm{T}}$, I. dokdonensis DS- $3^{\mathrm{T}}$, I. halotolerans YIM $70177^{\mathrm{T}}$ and I. chiayiensis $06182 \mathrm{M}-1^{\mathrm{T}}$, respectively. The phylogenetic tree based on 16S RNA gene sequences of strain $\mathrm{H} 17^{\mathrm{T}}$ and recognized species of the genus Isoptericola and other related species is shown in Fig. 1. In the phylogenetic tree based on the neighbour-joining algorithm, strain $\mathrm{H} 17^{\mathrm{T}}$ and I. variabilis $\mathrm{MX}^{\mathrm{T}}$ formed an independent cluster with a bootstrap value of $96 \%$ (Fig. 1).

The $\mathrm{G}+\mathrm{C}$ content of strain $\mathrm{H} 17^{\mathrm{T}}$ was $72.4 \mathrm{~mol} \%$, which was close to that found for other species of the genus Isoptericola. DNA-DNA hybridization studies showed relatively low relatedness values with $I$. variabilis $\mathrm{MX}^{\mathrm{T}}$ (45.6\%), I. hypogeus HKI $0342^{\mathrm{T}}$ (37.9\%), I. jiangsuensis $\mathrm{CLG}^{\mathrm{T}}(33.4 \%)$, I. dokdonensis DS-3 ${ }^{\mathrm{T}}(33.4 \%)$, I. halotolerans YIM $70177^{\mathrm{T}}(40.9 \%)$ and I. chiayiensis $06182 \mathrm{M}-1^{\mathrm{T}}$ $(15.2 \%)$. All of the values were significantly lower than $70 \%$, the threshold value recommended for the assignment of genomic species (Wayne et al., 1987). These results indicated that strain $\mathrm{H}_{17}{ }^{\mathrm{T}}$ represents a novel species of the genus Isoptericola, for which the name Isoptericola nanjingensis sp. nov. is proposed.

\section{Description of Isoptericola nanjingensis sp. nov.}

Isoptericola nanjingensis (nan.jing.en'sis. N.L. masc. adj. nanjingensis referring to Nanjing, Jiangsu Province, PR China, where the organism was first isolated).

Gram-positive-staining, aerobic, non-motile, non-sporeforming, coccus- or rod-shaped bacterium. Colonies are pale yellow, circular, convex, smooth and 1.0-2.0 $\mathrm{mm}$ in diameter after $48 \mathrm{~h}$ incubation at $30{ }^{\circ} \mathrm{C}$. The optimum temperature, $\mathrm{pH}$ and $\mathrm{NaCl}$ concentration for growth are $30{ }^{\circ} \mathrm{C}, 7.0$ and $3 \%(\mathrm{w} / \mathrm{v})$, respectively. In addition to the characteristics presented in Table $1, \mathrm{H}_{2} \mathrm{~S}$ is not produced and the type strain gives a negative result for the Voges-Proskauer test. The cellwall peptidoglycan type is L-Lys-D-Asp. The whole-cell sugars are galactose, xylose and mannose. The major fatty acids $(>10 \%$ of total $)$ are anteiso- $\mathrm{C}_{15: 0}$ and iso- $\mathrm{C}_{15: 0}$. The total polar lipids are diphosphatidylglycerol, phosphatidylglycerol, phospholipids, phosphatidylinositol, phosphoglycolipid, one unidentified glycolipid and one unidentified lipid. The menaquinone is $\mathrm{MK} 9\left(\mathrm{H}_{4}\right)$ (see Fig. S5). Mycolic acids are not detected.

The type strain, $\mathrm{H}_{1} 7^{\mathrm{T}} \quad\left(=\mathrm{DSM} \quad 24300^{\mathrm{T}}=\mathrm{CCTCC} \quad \mathrm{AB}\right.$ $2011005^{\mathrm{T}}$ ), was isolated from soil in Nanjing, Jiangsu, PR China. The DNA G + C content of the type strain is $72.4 \mathrm{~mol} \%$.

\section{Acknowledgements}

This research was supported by National Natural Science Foundation of China (project no. 41071173). The authors thank Professor Biao Shen (Nanjing Agricultural University) for providing I. jiangsuensis $\mathrm{CLG}^{\mathrm{T}}$. We thank Dr Peter Schumann of DSMZ for the analysis of peptidoglycan structure and cell-wall sugars and Dr Brian Tindall for the analysis of polar lipids and fatty acids. We also thank Dr Yongxia Wang of Yunnan University for the analysis of menaquinones and mycolic acids.

\section{References}

Bakalidou, A., Kämpfer, P., Berchtold, M., Kuhnigk, T., Wenzel, M. \& König, H. (2002). Cellulosimicrobium variabile sp. nov., a cellulolytic bacterium from the hindgut of the termite Mastotermes darwiniensis. Int J Syst Evol Microbiol 52, 1185-1192.

Chun, J., Lee, J.-H., Jung, Y., Kim, M., Kim, S., Kim, B. K. \& Lim, Y. W. (2007). EzTaxon: a web-based tool for the identification of prokaryotes based on $16 \mathrm{~S}$ ribosomal RNA gene sequences. Int J Syst Evol Microbiol 57, 2259-2261.

Collins, M. D., Pirouz, T., Goodfellow, M. \& Minnikin, D. E. (1977). Distribution of menaquinones in actinomycetes and corynebacteria. J Gen Microbiol 100, 221-230.

De Ley, J., Cattoir, H. \& Reynaerts, A. (1970). The quantitative measurement of DNA hybridization from renaturation rates. Eur $J$ Biochem 12, 133-142.

Gordon, R. E., Barnett, D. A., Handerhan, J. E. \& Pang, C. H.-N. (1974). Nocardia coeliaca, Nocardia autotrophica, and the nocardin strain. Int J Syst Bacteriol 24, 54-63.

Groth, I., Schumann, P., Schütze, B., Gonzalez, J. M., Laiz, L., SaizJimenez, C. \& Stackebrandt, E. (2005). Isoptericola hypogeus sp. nov., isolated from the Roman catacomb of Domitilla. Int J Syst Evol Microbiol 55, 1715-1719.

Kuykendall, L. D., Roy, M. A., O’Neill, J. J. \& Devine, T. E. (1988). Fatty acids, antibiotic resistance, and deoxyribonucleic acid homology groups of Bradorhizobium japonicum. Int J Syst Bacteriol 38, 358361.

Lányí, B. (1987). Classical and rapid identification methods for medically important bacteria. Methods Microbiol 19, 1-67.

Marmur, J. \& Doty, P. (1962). Determination of the base composition of deoxyribonucleic acid from its thermal denaturation temperature. J Mol Biol 5, 109-118.

Miller, L. T. (1982). Single derivatization method for routine analysis of bacterial whole-cell fatty acid methyl esters, including hydroxy acids. J Clin Microbiol 16, 584-586.

Minnikin, D. E., Hutchinson, G., Caldicott, A. B. \& Goodfellow, M. (1980). Thin-layer chromatography of methanolysates of mycolic acid-containing bacteria. J Chromatogr A 188, 221-233.

Schleifer, K. H. (1985). Analysis of the chemical composition and primary structure of murein. Methods Microbiol 18, 123-156.

Schleifer, K. H. \& Kandler, O. (1972). Peptidoglycan types of bacterial cell walls and their taxonomic implications. Bacteriol Rev 36, 407-477.

Stackebrandt, E., Schumann, P. \& Cui, X. L. (2004). Reclassification of Cellulosimicrobium variabile Bakalidou et al. 2002 as Isoptericola variabilis gen. nov., comb. nov. Int J Syst Evol Microbiol 54, 685-688.

Staneck, J. L. \& Roberts, G. D. (1974). Simplified approach to identification of aerobic actinomycetes by thin-layer chromatography. Appl Microbiol 28, 226-231.

Tamaoka, J., Katayama-Fujimura, Y. \& Kuraishi, H. (1983). Analysis of bacterial menaquinone mixtures by high performance liquid chromatography. J Appl Bacteriol 54, 31-36.

Timke, M., Wang-Lieu, N. Q., Altendorf, K. \& Lipski, A. (2005). Community structure and diversity of biofilms from a beer bottling plant as revealed using 16S rRNA gene clone libraries. Appl Environ Microbiol 71, 6446-6452.

Tindall, B. J. (1990a). A comparative study of the lipid composition of Halobacterium saccharovorum from various sources. Syst Appl Microbiol 13, $128-130$ 
Tindall, B. J. (1990b). Lipid composition of Halobacterium lacusprofundi. FEMS Microbiol Lett 66, 199-202.

Tseng, M., Liao, H. C., Chiang, W. P. \& Yuan, G. F. (2011). Isoptericola chiayiensis sp. nov., isolated from mangrove soil. Int J Syst Evol Microbiol 61, 1667-1670.

Wayne, L. G., Brenner, D. J., Colwell, R. R., Grimont, P. A. D., Kandler, O., Krichevsky, M. I., Moore, L. H., Moore, W. E. C., Murray, R. G. E. \& other authors (1987). International Committee on Systematic Bacteriology. Report of the ad hoc committee on reconciliation of approaches to bacterial systematics. Int J Syst Bacteriol 37, 463-464.

Whiton, R. S., Lau, P., Morgan, S. L., Gilbart, J. \& Fox, A. (1985). Modifications in the alditol acetate method for analysis of muramic acid and other neutral and amino sugars by capillary gas chromatography-mass spectrometry with selected ion monitoring. J Chromatogr A 347, 109-120.

Wu, Y., Li, W. J., Tian, W., Zhang, L. P., Xu, L., Shen, Q. R. \& Shen, B. (2010). Isoptericola jiangsuensis sp. nov., a chitin-degrading bacterium. Int J Syst Evol Microbiol 60, 904-908.

Yoon, J. H., Schumann, P., Kang, S. J., Jung, S. Y. \& Oh, T. K. (2006). Isoptericola dokdonensis sp. nov., isolated from soil. Int J Syst Evol Microbiol 56, 2893-2897.

Zhang, Y. Q., Schumann, P., Li, W. J., Chen, G. Z., Tian, X. P., Stackebrandt, E., Xu, L. H. \& Jiang, C. L. (2005). Isoptericola halotolerans sp. nov., a novel actinobacterium isolated from saline soil from Qinghai Province, north-west China. Int J Syst Evol Microbiol 55, 1867-1870. 